\title{
Optimization of Limestone-gypsum Wet Flue Gas Desulfurization
}

\author{
System \\ Jing Han, Guoyue Zhu \\ Enviromental Department \\ Tianjin JunLiangcheng CO.,LTD Tianjin 300300,China \\ 879937927@qq.com
}

Keyword: tower, optimization, desulfurization, slurry, water

Abstract. Two 350MW Boilers is operating in Tianjin Junliangcheng Generation Co. Ltd. Limestone - gypsum wet FGD with two towers is adopted. Some optimization of pH and density, slurry and process water are made: the $\mathrm{PH}$ and densimeter are placed at the outlet of the recycled pump tube, it could make the discharged pump stop operating when gypsum are not draint. absorption tower sump pump can be slurry to another absorption tower adjacent, shorten the time of emptying the absorption tower; two sets of process water system is connected to the standby for each other, provides a good the conditions for maintenance personnel to deal with defects, on the other hand to ensure the stable operation of the system.

\section{Introduction}

The limestone/gypsum wet desulfurization is used for 350MW boiler of Tianjin JunLiangcheng generation co., LTD. In the past five years, combined with problems of operation and repairing, some optimization is made to ensure the stable operation of the system. This article can give some advice to the workers of desulfurization.

\section{The optimization of $\mathrm{PH}$ and densimeter equipment}

The $\mathrm{pH}$ and densimeter is placed at the main pipe of discharged pump. The $\mathrm{PH}$ of desulfurization tower should be maintained at 5.0-6.2.value not only caused by low $\mathrm{pH}$ with being reduced the removal efficiency of sulfur dioxide. But it is difficult to dissolve limestone at high $\mathrm{pH}$, absorbent is wasted. So the $\mathrm{pH}$ is monitored constantly. The discharged pump is needed to operate. The life of discharged pump is shortened and the power consumption of desulfurization is increased at this operation. To solve these problems, the PH and densimeter are placed at a recycled pump of the outlet. The discharged pump is operated when gypsum is needed to replace.

\section{The optimization of pit pipeline}

The pit of absorbed tower is collected flushing and cooling water. The pump is started to return slurry to tower usually when the level is reached a certain height. The absorption tower is needed to empty when being repaired. The slurry is discharged to accident tank. But the water also is returned to tower when the pit is nearly full. It takes a long time to empty the tower. Especially in winter, the accident tank is stopped running in order to antifreeze accident slurry tank. For gaining more time for maintenance, a pipe is added to the adjacent absorption tower. 


\section{The optimization of water system}

Before the transformation, the boiler has one desulfurizer. Another absorption tower is added when the transformation. The desulfurization has two absorption towers. At the same time, a set of water system which the wash water for tower B is built. During the desulfurization system is operated normally, the water is played an important role, not only is it supply water for towers, also as cooling water and washing water. So the stable operation of water subsystem is ensured the whole desulfurization system. For this, the new water system and the original water system are connected. It is provided favorable conditions for maintenance and safer operation.

\section{Summary}

The more important Environmental issues is became, the stricter flue gas index of coal-fired power plant is. Desulfurization system is the fourth main system for power plants.So some improvement must to be made to ensure its stable operation.

The $\mathrm{pH}$ and densimeter are placed at outlet of circulating pump, the extended discharge pump is extended its use time and power consumption is save.

Another pipe is added for the outlet of pit to adjacent absorption tower,it is shorten the time of cleaning out tower. More repair time is economized.

The new water system and the original water system are connected. It is provided favorable conditions for maintenance and safer operation.

\section{References}

1. D. Karatza, M. Prisciandaro, A. Lancia and, D. Musmarra. Calcium Bisulfite Oxidation in the Flue Gas Desulfurization Process Catalyzed by Iron and Manganese Ions. Journal of the Air \& Waste Management Association, 2004, 60(6):675-80

2. S Khanna, AK Srivastava. POPULAR CONSTITUTIONALISM IN THE TWENTIETH CENTURY: Reflections on the Dark Side, the Progressive Constitutional Imagination, and the Enduring Role . Chicago-Kent Law Review, 2006, 29(3):574-582

3. L Chen, C Ramsier, J Bigham, B Slater, D Kost. Oxidation of FGD-CaSO 3 and effect on soil chemical properties when applied to the soil surface. 《Fuel》, 2009, 88(7):1167-1172

4. D Karatza, M Prisciandaro, A Lancia, D Musmarra. Reaction rate of sulfite oxidation catalyzed by cuprous ions. 《Chemical Engineering Journal》, 2008, 145(2):285-289

5. JS Mo, ZB Wu, CJ Cheng, BH Guan, WR Zhao. Oxidation inhibition of sulfite in dual alkali flue gas desulfurization system. 《Journal of Environmental Sciences》, 2007, 19(2):226-231

6. Y Mathieu, L Tzanis, M Soulard, J Patarin, M Vierling. Adsorption of SOx by oxide materials: A review. 《Fuel Processing Technology》, 2013, 114(3):81 - 100

7. LE Kallinikos, EI Farsari, DN Spartinos, NG Papayannakos. Simulation of the operation of an industrial wet flue gas desulfurization system. 《Fuel Processing Technology》, 2010, 91(12):1794-1802

8. B Guan, H Fu, J Yu, G Jiang, B Kong. Direct transformation of calcium sulfite to a -calcium 
sulfate hemihydrate in a concentrated $\mathrm{Ca}-\mathrm{Mg}-\mathrm{Mn}$ chloride solution under atmospheric pressure. 《Fuel》, 2011, 90(1):36-41

9. C Wang, H Liu, XZ Li, J Shi, G Ouyang. A new concept of desulfurization: the electrochemically driven and green conversion of SO2 to NaHSO4 in aqueous solution. 《Environmental Science \& Technology》, 2008, 42(22):8585-90

10. D Karatza, M Prisciandaro, A Lancia, D Musmarra. Sulfite oxidation catalyzed by cobalt ions in flue gas desulfurization processes.. 《Journal of the Air \& Waste Management Associat..., 2010, 60(6):675

11. G Kracker - Semler, R Marr, M Siebenhofer. Experimental Investigation and Modeling of Catalytically Supported Sulfite/Bisulfite Oxidation with Oxygen. 《Chemical Engineering \& Technology》, 2004, 27(6):630-633

12. C Huang, $\mathrm{T} \mathrm{Xu}$. Comparative study on the regeneration of flue-gas desulfurizing agents by using conventional electrodialysis (ED) and bipolar membrane electrodialysis (BMED).. 《Environmental Science \& Technology》, 2006, 40(17):5527-31

13. ALV Perales, P Ollero, FJG Ortiz, VB F. Dynamic Analysis and Identification of a Wet Limestone Flue Gas Desulfurization Pilot Plant. 《Industrial \& Engineering Chemistry Research》, 2008, 47(21):8263-8272

14. GMD Celso, D Karatza, A Lancia, D Musmarra, M Prisciandaro. Limestone-Gypsum Flue Gas Desulfurization Process: Modeling of Catalyzed Bisulfite Oxidation. International Conference on Chemical \& Process ..., 2013, 32:781-786

15. T Recelj, J Golob. Equilibrium and Mass Transfer in the Ca 2+ - SO $2-\mathrm{H} 2 \mathrm{O}$ System for the Analysis of the Flue Gas Desulphurization Process. 《Process Safety \& Environmental Protection》, 2004, 82(5):371-380 